University of Nebraska - Lincoln

DigitalCommons@University of Nebraska - Lincoln

Biological Systems Engineering: Papers and

Publications

Biological Systems Engineering

2008

\title{
Construction, Installation, and Performance of Two Repacked Weighing Lysimeters
}

José O. Payero

Queensland Department of Primary Industries and Fisheries, jpayero@clemson.edu

Suat Irmak

University of Nebraska-Lincoln, suat.irmak@unl.edu

Follow this and additional works at: https://digitalcommons.unl.edu/biosysengfacpub

Part of the Biological Engineering Commons

Payero, José O. and Irmak, Suat, "Construction, Installation, and Performance of Two Repacked Weighing Lysimeters" (2008). Biological Systems Engineering: Papers and Publications. 49.

https://digitalcommons.unl.edu/biosysengfacpub/49

This Article is brought to you for free and open access by the Biological Systems Engineering at DigitalCommons@University of Nebraska - Lincoln. It has been accepted for inclusion in Biological Systems Engineering: Papers and Publications by an authorized administrator of DigitalCommons@University of Nebraska Lincoln. 
Published in Irrigation Science 26 (2008), pp. 191-202; doi 10.1007/ s00271-007-0085-9

Copyright (C) Springer-Verlag 2007. Used by permission.

Submitted February 8, 2007; accepted August 9, 2007; published online August 28, 2007.

Communicated for Irrigation Science by T. Trooien.

\title{
Construction, installation, and performance of two repacked weighing lysimeters
}

\author{
José O. Payero ${ }^{1}$ and Suat Irmak ${ }^{2}$ \\ ${ }^{1}$ Irrigated Farming Systems, Queensland Department of Primary Industries and Fisheries (DPI\&F), 203 Tor Street, Toowoomba, \\ QLD, 4350, Australia (Corresponding author; email jose.payero@dpi.qld.gov.au ) \\ ${ }^{2}$ Department of Biological Systems Engineering, University of Nebraska-Lincoln, 234 L.W. Chase Hall, Lincoln, NE 68583-0726, \\ USA (email sirmak2@unl.edu )
}

\begin{abstract}
Weighing lysimeters are the standard method for directly measuring evapotranspiration (ET). This paper discusses the construction, installation, and performance of two $(1.52 \mathrm{~m} \times 1.52 \mathrm{~m} \times 2.13-\mathrm{m}$ deep) repacked weighing lysimeters for measuring ET of corn and soybean in West Central Nebraska. The cost of constructing and installing each lysimeter was approximately US $\$ 12,500$, which could vary depending on the availability and cost of equipment and labor. The resolution of the lysimeters was $0.0001 \mathrm{mV} \mathrm{V}^{-1}$, which was limited by the data processing and storage resolution of the datalogger. This resolution was equivalent to 0.064 and $0.078 \mathrm{~mm}$ of ET for the north and south lysimeters, respectively. Since the percent measurement error decreases with the magnitude of the ET measured, this resolution is adequate for measuring ET for daily and longer periods, but not for shorter time steps. This resolution would result in measurement errors of less than $5 \%$ for measuring ET values of $\geq 3 \mathrm{~mm}$, but the percent error rapidly increases for lower ET values. The resolution of the lysimeters could potentially be improved by choosing a datalogger that could process and store data with a higher resolution than the one used in this study.
\end{abstract}

\section{Introduction}

Accurate crop evapotranspiration (ET) data are required to improve agricultural water resources management. Micrometeorological techniques such as the Bowen ratio and Eddy covariance methods have become popular in recent times for directly measuring ET
(Payero et al. 2003; Todd et al. 2000a; Verhoef et al. 1999; Liu and Kotoda 1998; Laubach et al. 1994). However, lysimeters are still considered as the standard method to directly measure ET. Lysimeters have a long history of development and different designs have been used (Howell et al. 1991).

Lysimeters have been designed in different shapes and sizes. Shapes include square (Marek et al. 1988; Schneider et al. 1998), circular (Pruitt and Angus 1960; McFarland et al. 1983; Meshkat et al. 1999; Seyfried et al. 2001; Yang et al. 2003; Young et al. 1997), and rectangular (Schneider et al. 1996; Malone et al. 2000; Klocke et al. 1985; Tyagi et al. 2003; Marek et al. 2006). The size of lysimeters also varies significantly. While the lysimeter designed by Meshkat et al. (1999) only had an area of $0.44 \mathrm{~m}^{2}$, the lysimeter designed by Pruitt and Angus (1960) had an area of $28.27 \mathrm{~m}^{2}$ (6 $\mathrm{m}$ in diameter). The size is a function of the intended use and the required or desired resolution. Researchers also use lysimeters with an area as small as $0.006 \mathrm{~m}^{2}$, usually known as microlysimeters or minilysimeters, to measure evaporation of soil water (Todd et al. 2000b; Evett et al. 1995).

According to how the soil inside the lysimeter is collected, lysimeters can be monolithic, repacked (or reconstructed), or a combination of both. In monolithic lysimeters, the soil inside the lysimeter is an intact soil core (Marek et al. 1988, 2006; Malone et al. 2000; Seyfried et al. 2001; Meshkat et al. 1999). In reconstructed or repacked lysimeters, the soil inside the lysimeter is disturbed soil 
that is repacked to try and mimic the characteristics of the intact soil (McFarland et al. 1983; Yang et al. 2003). Schneider et al. (1996) designed and installed a lysimeter with a combination of monolithic and repacked soil. Although natural soil characteristics can only be preserved with monolithic lysimeters, extracting a monolith could significantly increase the cost of the lysimeter because it could require specialized techniques, labor, and equipment to extract the monolith, as described by Schneider and Howell (1991), Schneider et al. (1988, 1993, 1996), and Meshkat et al. (1999).

Lysimeters can be weighing and non-weighing. The non-weighing types are used to determine ET as a residual by measuring all other components of the soil water balance, including water inputs (rain and irrigation), outputs (drainage and runoff), and change in soil water storage (Garcia et al. 2004). Non-weighing lysimeters, also called percolation or drainage lysimeters, are also used in percolation and solute transport studies (Klocke et al. 1993, 1999). Weighing lysimeters, on the other hand, measure crop ET directly by measuring the change in mass of an isolated soil volume. The ET calculated from the mass changes, however, needs to be adjusted to account for mass changes caused by factors other than ET, such as drainage or water input (Malone et al. 2000). Weighing lysimeters have been designed using different weighing mechanisms. Weighing mechanisms include hydraulic (Hanks and Shawcroft 1965; Klocke et al. 1985; Seyfried et al. 2001), suspended load cells (Allen and Fisher 1990; Tyagi et al. 2003), deck scales (Marek et al. 2006; Schneider et al. 1998; Kirkham et al. 1984), load cells installed at the bottom of the lysimeter (Allen and Fisher 1990; McFarland et al. 1983), single load cell with counter-balance (Pruitt and Angus 1960; van Bavel and Myers 1962; Hunsaker et al. 2002; Marek et al. 1988; Malone et al. 2000; Meshkat et al. 1999; Young et al. 1997; Yoder et al. 2005), and flexurelevel action balance with a load cell (Howell et al. 1985; Phene et al. 1989).

The cost of constructing and installing a lysimeter can vary considerably, and is mainly affected by its size, type of material, whether a monolithic or repacked soil is used, and especially by the type of weighing mechanism. Lysimeters with counter-balance mechanisms are usually much more expensive than those that do not have a counter-balance system. The cost of installing lysimeters with no counter-balance mechanism can be considerably less than purchasing alternative micrometeorological equipment (Bowen ratio or Eddy covariance) to measure ET. For example, the total cost of installing a set of two lysimeters was reported by McFarland et al. (1983) as US $\$ 10,719$; by Kirkham et al. (1984) under US $\$ 10,000$; and by Allen and Fisher (1990) as US $\$ 11,000$. On the other hand, the cost of constructing and installing counter-balanced lysimeters could be hundreds of thousands US\$ (Marek et al. 1988).

The sensitivity or resolution of lysimeters is extremely important for accurate ET measurements. Schneider and Howell (1991) indicated that lysimeter accuracy was directly proportional to the surface area and the accuracy of the scale, and inversely proportional to the lysimeter mass. Allen and Fisher (1990) found that the sensitivity was also limited by the resolution of the datalogger or data recording system. The sensitivities reported in the literature for lysimeters of different surface areas, weighing systems, and data recording systems (Table 1) show that sensitivities vary considerably, and that comparable sensitivities have been reported for lysimeters with and without counter-balance mechanism. This paper discusses the construction, field installation, and performance of two repacked weighing lysimeters for measuring ET of corn and soybean in West Central Nebraska.

\section{Materials and methods}

Design and construction

\section{General description}

Each lysimeter consists of an inner and an outer steel box. The inner box is filled with soil, where a crop can be planted. The inner box rests on three electronic load cells bolted to the bottom of the outer box. The load cells automatically measure the mass of the inner box at regular intervals. The electronic signal from the load cells is measured and stored using a datalogger installed on a tower outside the lysimeter. Differences in the mass of the inner box generally indicate water inputs or outputs. A drainage system was installed inside the inner box to collect excess water.

\section{Lysimeter boxes}

The lysimeter boxes were constructed of welded 6.4$\mathrm{mm}$ plate steel by a local welding shop (Troyer Enterprises, Inc., North Platte, NE, USA) (Figure 1). They were reinforced with four 76-mm steel channels $\left(6.1 \mathrm{~kg} \mathrm{~m}^{-1}\right)$ welded horizontally, and evenly spaced, to the outside of the outer box and to the inside of the inner box. This arrangement allowed leaving a small gap of about $3 \mathrm{~cm}$ between the outer and inner boxes, and was expected to minimize direct water flow along the inner side of the walls of the inner box. Reinforcements were also welded inside the bottom of the outer box and outside the bottom of the inner box. 
Table 1. Sensitivities reported in the literature for lysimeters of different areas, weighing systems and data recording systems

\begin{tabular}{|c|c|c|c|c|c|}
\hline Reference & Data recording ${ }^{\mathrm{a}}$ & Area $\left(\mathrm{m}^{2}\right)$ & Depth (m) & Weighing system ${ }^{b}$ & Sensitivity (mm of water) \\
\hline Pruitt and Angus (1960) & ) Printer & 28.27 & 0.91 & LC-W-CB & 0.03 \\
\hline Kirkham et al. (1984) & CR-7 & 2.31 & 1.30 and1.60 & DS-WO-CB & 0.02 \\
\hline Howell et al. (1985) & PC & 4.0 & 2.00 & LC-W-FLAB & 0.02 \\
\hline Marek et al. (1988) & CR-7X & 9.0 & 2.30 & LC-W-CB & 0.045 \\
\hline Schneider et al. (1993) & CR-21X & 0.75 & 2.30 & LC-WO-CB & 0.47 \\
\hline Howell et al. (1995) & CR-7X & 9.0 & 2.30 & LC-W-CB & 0.05 \\
\hline Young et al. (1997) & CR-7 & 4.91 & 4.00 & LC-W-CB & 0.04 \\
\hline Schneider et al. (1998) & CR-7 & 2.25 and 3.0 & 2.44 and 1.60 & DS-WO-CB & 0.1 and 0.02 \\
\hline Meshkat et al. (1999) & PC & 0.44 & 0.80 & LC-W-CB & 0.025 \\
\hline Yang et al. (2003) & PC & 1.77 & 1.60 & NS & 0.028 \\
\hline Yoder et al. (2005) & NS & 4.0 & 1.80 & LC-W-CB & 0.05 \\
\hline Marek et al. (2006) & CR23X & 3.0 & 2.50 & DS-WO-CB & 0.0036 \\
\hline
\end{tabular}

a Printer = lysimeter mass changes were continuously printed on paper. Most of these data recording systems are datalogger models manufactured by Campbell Scientific, Inc., Logan, UT, USA; PC personal computer, instrumented with some kind of data acquisition system. NS not specified

${ }^{b} L C-W-C B$ load cell with counter-balance, $L C-W O-C B$ load cell without counter-balance, $D S-W O-C B$ deck scale without counter-balance, $L C-W$ FLAB load cell with flexure-level action balance

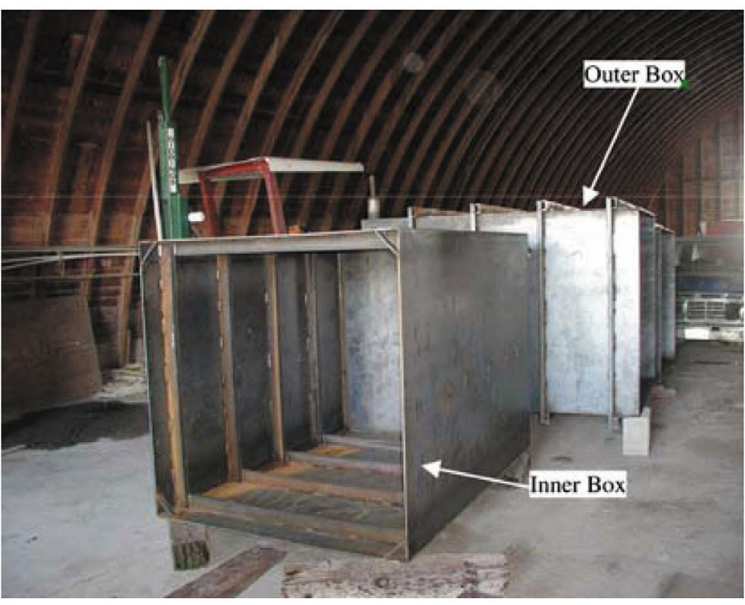

Figure 1. Inner and outer lysimeter boxes as received from the welding shop.

The inner box had inside dimensions of $1.52 \mathrm{~m} \times$ $1.52 \mathrm{~m} \times 2.13-\mathrm{m}$ deep to accommodate two rows of corn or soybean planted at a row spacing of $0.76 \mathrm{~m}$. The 1.52$\mathrm{m}$ size was selected because it was an integer multiple of the crop row spacing, as suggested by Howell et al. (1991). The 2.13-m depth was considered adequate to grow corn without significantly restricting nor- mal root development and soil water extraction. Previous research at this site had shown that although corn could extract water from a depth of more than $2 \mathrm{~m}$, water was predominantly extracted from approximately the top $1.5 \mathrm{~m}$ (Payero et al. 2006). The outer box was $1.60 \mathrm{~m} \times 1.60 \mathrm{~m} \times 2.29-\mathrm{m}$ deep, slightly larger than the inner box to leave a gap between the two boxes, and allow free up and down movements of the inner box. The outer box was also $16 \mathrm{~cm}$ deeper to provide space for the weighing system. All boxes were spray-painted with two coats of paint to prevent corrosion.

\section{Drainage system}

The drainage system consisted of gravity and vacuum drains (Figs. 2, 3) to allow drainage under saturated and unsaturated soil conditions. The U-shaped gravity drain (1.2-m long $\times$ 0.91-m wide) was constructed from 10.2$\mathrm{cm}$ diameter PVC pipe and fittings. Slots were made on the two legs of the gravity drain using a power bench saw. The slots were approximately $6.4-\mathrm{mm}$ wide by 76-mm long and were separated approximately every $50 \mathrm{~mm}$. The two legs of the gravity drain were covered with a filtering material to prevent soil particles from entering the drain while still allowing water flow. The filtering material consisted of a layer of EnviroFlex well 


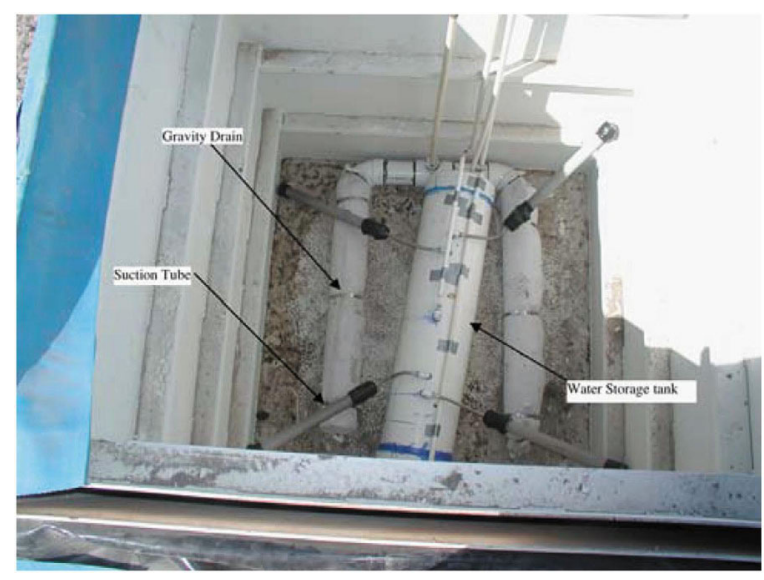

Figure 2. Top view of the inner lysimeter tank showing the components of the gravity and vacuum drain systems.

screen (Titan Industries, Inc., Paxton, NE, USA) covered with an Aqua-Sleeve ${ }^{\mathrm{TM}}$ well screen filter sock (Carriff Corporation, Inc., Midland, NC, USA). The filtering material was fastened to the pipe using steel hose clamps.

A PVC vertical pipe (19-mm diameter) was connected to the center of the gravity drain, which extended along one of the lysimeter walls to $0.3 \mathrm{~m}$ below the soil surface inside the inner box. A copper tube [6.4-mm outside diameter (OD)] was inserted inside the vertical PVC pipe, extending from the bottom of the inner box to just above the soil surface. The gap between the copper and PVC tubes was sealed with silicone. The copper tube was used to pump the water out of the gravity drain.

The vacuum drain consisted of four suction tubes connected to a water storage tank (Figure 2). The suction tubes (64-mm long $\times 50-\mathrm{mm} \mathrm{OD})$ were made of porous sintered stainless steel with a pore size of $0.5 \mu \mathrm{m}$ (GKN Sinter Metals Filters, Addison, IL, USA). They were connected to the upper part of the storage tank using flexible tubes (13-mm OD) with a braided stainless steel cover, commonly used to supply water to residential water heaters.

The storage tank $(1.2-\mathrm{m}$ long $\times 30.5 \mathrm{~cm}$ diameter $)$ was constructed from a PVC pipe capped at both ends. It was hermetically sealed because it was going to be used to store drainage water and as a vacuum source for the suction tubes. Several polyethylene tubes (9.5-mm OD and 6.4-mm ID) were connected to the storage tank. Two tubes were connected to the bottom of the tank to be used as drains. Another tube was connected to the top of the tank, which was used to apply suction and create a vacuum inside the tank.

Suction to the tank was applied with a TD-4X2NA vacuum pump (Brailsford \& Company, Inc., Antrim, $\mathrm{NH}, \mathrm{USA}$ ). This brushless DC motor-driven diaphragm- type pump could pump air or gases in either a vacuum draw or a pressure mode and was designed to operate continuously with a minimum service life in excess of 10,000 $\mathrm{h}$. The pump required 9-14 V DC and could pump 3-4 $1 \mathrm{~min}^{-1}$ at $12 \mathrm{~V}$, with a $2-\mathrm{W}$ power draw. Power to the pump was supplied by a car battery $(12 \mathrm{~V}$, 75 A) that was recharged by an MSX20 20-W solar panel (Campbell Scientific, Inc., Logan, UT, USA). A pump operated by DC power was required since the lysimeters were installed in the middle of an irrigated field and bringing $\mathrm{AC}$ power to the site would have been very costly and impractical.

A vacuum tank (Figure 3) was placed between the vacuum pump and both the storage tanks, and the gravity drain to avoid water entering and damaging the pump. The tank was fabricated from an air tank (26.5 l) (Campbell Hausfeld, Harrison, OH, USA). Seven polyethylene tubes $(9.5-\mathrm{mm}$ OD $\times 6.4-\mathrm{mm}$ ID) were connected to the vacuum tank. The tubes extended from the vacuum pump (two tubes), the bottom of the outer lysimeter box (one tube), the gravity drain (one tube), the top of the storage tank (one tube), and the bottom of the storage tank (two tubes) (Figure 3). The vacuum tank was connected to the drainage system using either polyethylene or copper tubes. Flexible plastic tubes (4.8mm ID) were used to connect the vacuum tank to the polyethylene or copper tubes coming out of the drainage system. The vacuum tank also had a drainage outlet at the bottom of the tank, and a transparent stand pipe to show the water level inside the tank. A copper hand valve was installed to open and close each tube as needed.

\section{Weighing system}

Three electronic load cells were installed in a triangular pattern inside the bottom of the outer box, similar to the design described by McFarland et al. (1983) and Allen and Fisher (1990). It was calculated that when the soil was at saturation, the mass of the inner lysimeter box would be approximately 10,000 kg. Based on this mass, hermetically sealed model 65083-10 K-0100 beam load cells (Sonsortronics, Covina, CA, USA) were selected, which had the factory specifications shown in Table 2.

The outputs of the load cells were sampled every minute and averages (10-min and hourly) were recorded using a CR23X datalogger (Campbell Scientific, Inc.). Since these load cells have a four-conductor cable, measurements were made by applying an excitation voltage of $5,000 \mathrm{mV}$ to a full bridge and making a differential voltage measurement of the bridge output using an output range of $15 \mathrm{mV}$. The load cells were connected directly to the datalogger, and the output of each load cell was 
Figure 3. Vacuum tank: a diagram showing what each of the outlets was connected to, and $\mathbf{b}$ as constructed and installed in the field.

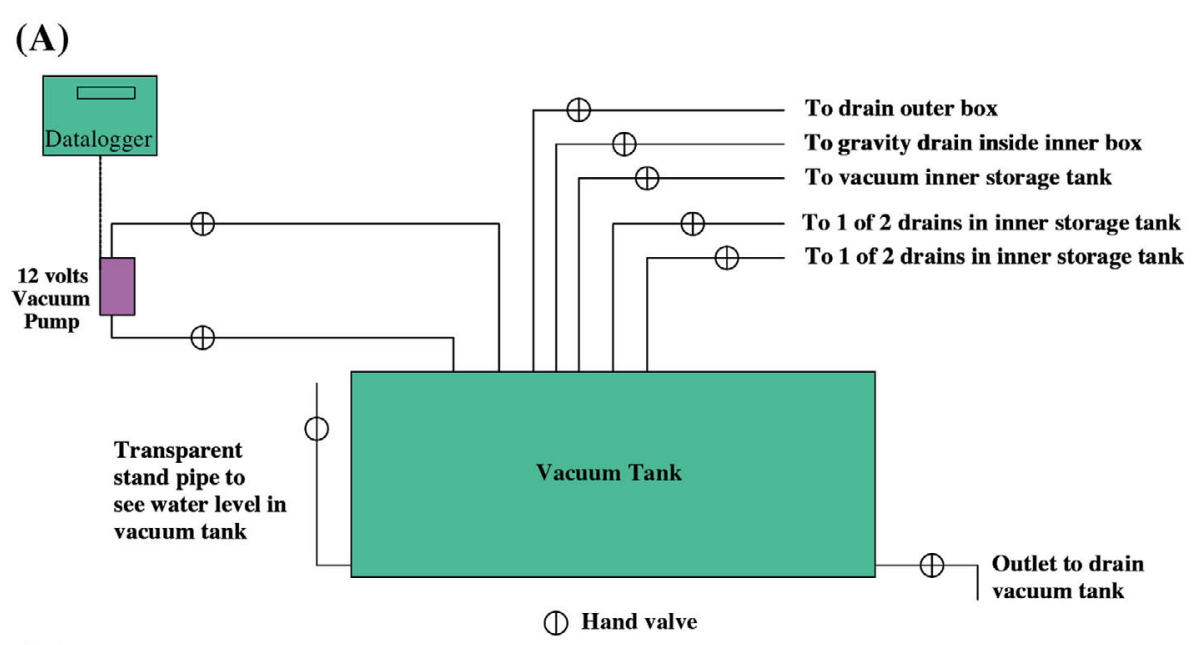

(B)

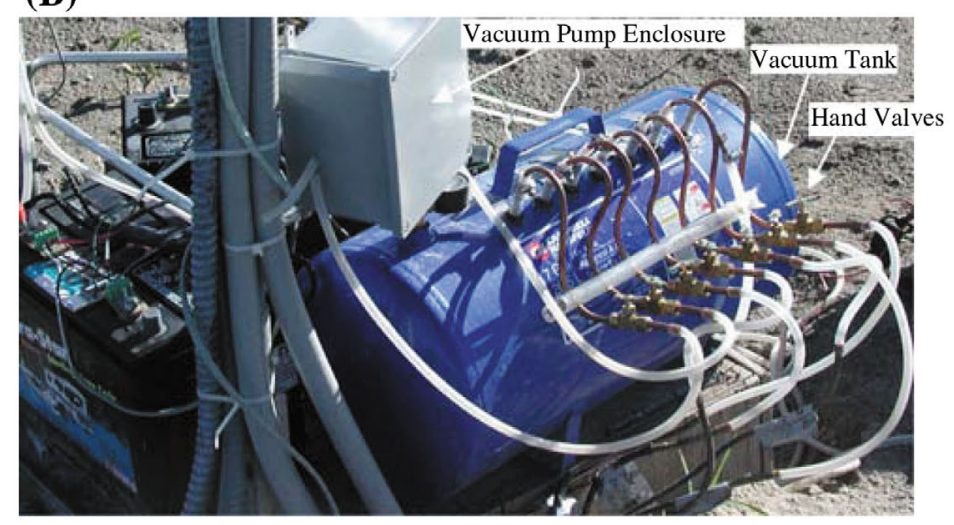

recorded separately in addition to the sum of the outputs of all three load cells.

\section{Soil water measurement}

A neutron probe access tube was installed in each lysimeter to monitor the soil water content every $0.30 \mathrm{~m}$. Also, six automatic $\mathrm{ECH}_{2} \mathrm{O}$ dielectric aquameters (model EC-20) (Decagon Devices, Inc., Pullman, WA, USA) were installed vertically at $0.30-\mathrm{m}$ depth increments from the surface for more frequent soil water measurements. The soil water content inside the lysimeter could be used as an alternative soil water balance methodology to estimate ET. It could also be used for irrigation scheduling to make sure that the crop planted in the lysimeter was not water-stressed.

\section{Field installation}

\section{Site description}

The lysimeters were installed in early May of 2004 in a 21.6-ha field at the University of Nebraska-Lincoln West Central Research and Extension Center in North Platte, NE, USA $\left(41.1^{\circ} \mathrm{N}, 100.8^{\circ} \mathrm{W}\right.$, elevation $\left.=861 \mathrm{~m}\right)$. The field was $499 \mathrm{~m}$ (north-south) $\times 433 \mathrm{~m}$ (east-west), divided into two subfields. The north side was $233 \mathrm{~m} \times 433 \mathrm{~m}$ (10.1 ha) and the south side, $265 \mathrm{~m} \times 433 \mathrm{~m}$ (11.5 ha). Corn and soybean were rotated between the two subfields, with both crops planted each year. One lysimeter was installed near the center of each subfield, which provided more than $100 \mathrm{~m}$ of fetch for each lysimeter in all directions. Howell et al. (1991) reported that many investigators recommended the lysimeter site to have an upwind fetch distance greater than $50 \mathrm{~m}$ and field area of $1 \mathrm{ha}$. Installing one lysimeter in each subfield allowed measuring ET for both crops in the same growing season. A weather station that is part of the High Plains Regional Climate Center (HPRCC) weather network was located at the eastern edge of the field. It measures all variables needed to calculate reference evapotranspiration $\left(\mathrm{ET}_{\mathrm{o}}\right)$, including solar radiation, maximum and minimum air temperatures, relative humidity, and wind speed. Data from the weather station were available for download from the HPRCC web site - http:// www.hprcc.unl.edu/home.html - as hourly or daily averages.

\section{Digging pit and describing soil profile}

The inner lysimeter box was filled with repacked soil, instead of a monolith. Effort was made to try and mimic 
Table 2. Factory specifications for the Sensortronics model 65083-10K-0100 load cell

\begin{tabular}{ll}
\hline Parameter & Value \\
\hline Capacity & $4,536 \mathrm{~kg}(10,000 \mathrm{lb})$ \\
Type & Shear beam \\
Material & Stainless steel \\
Applications & Hostile environments \\
Cable & $6 \mathrm{~m}$ of 4 -conductor \\
Operating temperature Range & $-18^{\circ} \mathrm{C}$ to $65^{\circ} \mathrm{C}\left(0\right.$ to $\left.150^{\circ} \mathrm{F}\right)$ \\
Safe overload & $150 \%$ of rated capacity \\
Ultimate overload & $300 \%$ of rated capacity \\
Creep (20 min) & $<0.03 \% \mathrm{FSO}$ \\
Non-repeatability & $<0.01 \% \mathrm{FSO}$ \\
Barometric effect & $\mathrm{Nil}$ \\
Zero balance & $\leq 1 \% \mathrm{FSO}$ \\
Thermal zero shift & $\leq 0.0015 \% \mathrm{FSO} /{ }^{\circ} \mathrm{F}$ \\
Thermal span shift & $\leq 0.0008 \% \mathrm{FSO} /{ }^{\circ} \mathrm{F}$ \\
Combined error & $\leq 0.03 \% \mathrm{FSO}=0.0003 \mathrm{~kg} \mathrm{~kg}-1$ \\
Maximum excitation & $15 \mathrm{Vac}$ or Vdc \\
Input resistance & $350 \mathrm{Ohms}$ \\
Insulation resistance & $>1,000 \mathrm{MOhms} @ 50 \mathrm{Vdc}$ \\
Full scale output (FSO) & $3.0 \mathrm{mV} \mathrm{V}-1 \pm 0.25 \%$ \\
\hline Creep is the &
\end{tabular}

${ }^{a}$ Creep is the change in load cell output occurring with time while under constant load and with all environmental conditions and other variables remaining constant

${ }^{\mathrm{b}}$ Non-repeatability is the maximum difference between load cell output readings for repeated loadings under identical loading and environmental conditions

the soil profile characteristics in the lysimeter to resemble those in the field. A backhoe was used to dig a pit approximately 2.4-m deep at each lysimeter site. A soil classification expert from the Natural Resources Conservation Service (NRCS) described in detail the soil profiles at each site, which are included in Payero (2005). At the time of installation, due to spring rain, the water table in the north lysimeter pit had risen to a depth of about $2.1 \mathrm{~m}$, and there was a depth of approximately $0.3 \mathrm{~m}$ of water standing at the bottom of the pit. At the south lysimeter site, however, the water table was deeper than $2.4 \mathrm{~m}$ and there was no water in the pit.

\section{Lysimeter foundation}

After digging the pit, a solid foundation to support the mass of the lysimeter boxes was constructed. First, a layer of sewer rocks (approximately 20-cm deep) was poured into the bottom of the pit and packed with the bucket of a backhoe. A leveled wooden frame $(2.1 \mathrm{~m} \times 2.1 \mathrm{~m} \times 0.15-\mathrm{m}$ height) was constructed on top of the rock base, which was then filled with concrete

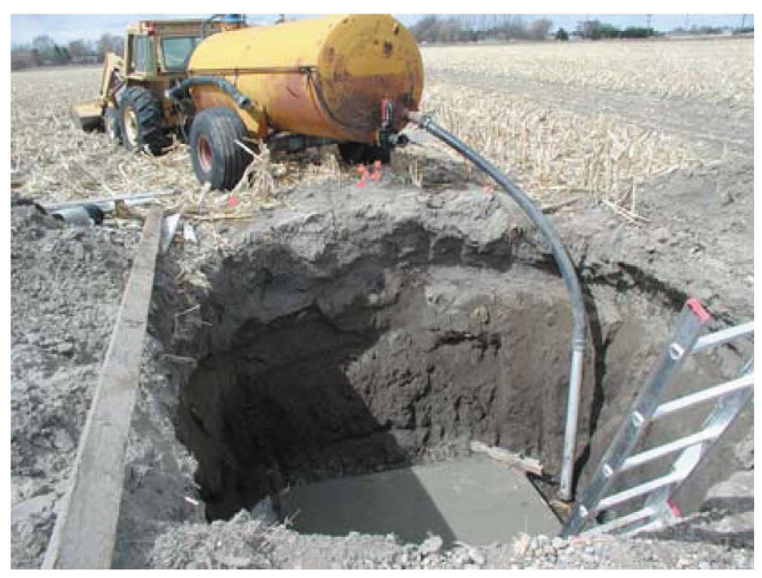

Figure 4. Pumping the water out of the north lysimeter pit to allow curing of the concrete base.

(Figure 4). Since there was water at the bottom of the north lysimeter pit, it was necessary to pump the water out before pouring the concrete and also while the concrete was curing. Water was pumped out of the pit using a centrifugal pump that was attached to a storage tank installed on a trailer (Figure 4). A tractor was used to carry the trailer and also to supply power to drive the pump. In the north lysimeter pit, a $15-\mathrm{cm}$ diameter drainage pipe was installed horizontally under the concrete base, which was connected to the soil surface by a $10-\mathrm{cm}$ diameter standing PVC pipe. The drainage pipe was installed to release the upward pressure from the water table on the concrete base.

\section{Installing the outer lysimeter box}

Before lowering the outer box in the pit, the material to cover the gap (gap cover) was installed forming a loop between the inner and outer lysimeter boxes. This material was taken from a $15-\mathrm{cm}$ diameter lay-flat flexible irrigation pipe. After the concrete base had cured for 5 days, the outer lysimeter box was installed on top of the concrete base, and the pit around the outside of the outer box was back-filled with part of the soil that was originally taken out of the pit. The outer lysimeter box was set in the pit using a crane (Figure 5). The outer box was positioned so that the two crop rows planted inside the lysimeter would be aligned with those planted in the field. A polyethylene tube (6.4 mm ID) was installed inside the outer box to be able to drain water from the box if needed (Figure 6).

\section{Load cell installation}

The load cells were bolted to plates welded to the channels at the bottom of the outer box, using two $64 \mathrm{~mm}$ $\times 19$-mm fine-thread steel bolts (Figure 6). One bolt was 


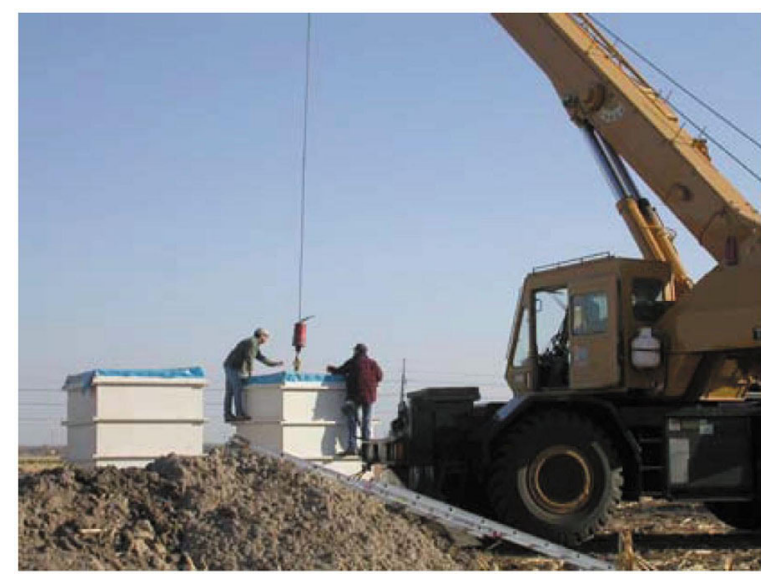

Figure 5. Installation of the inner and outer boxes of the weighing lysimeters at North Platte, NE, USA.

also attached to the other end of the load cell to support the inner lysimeter box (support bolt). A torque of $169 \mathrm{~N} \mathrm{~m}$ was applied to the mounting bolts as recommended by the load cell manufacturer. The cables of all the load cells were inserted inside a conduit to protect them from rodent and moisture damage (Figure 6).

\section{Installation of the inner lysimeter box}

The inner box was lowered inside the outer box and was set in place making sure that the sides of the two boxes were not touching, and that an adequate gap was left in all sides. The gap between the two boxes was then covered, using the "gap cover" to prevent water, soil, and rodents from getting inside the outer box.

\section{Installing the drainage system}

Before installation, the vacuum drainage system was tested in the laboratory to make sure that the pump was able to pump water from the bottom of the lysimeter. The system was tested by immersing each of the four suction tubes in a water tank (113 l) and applying suction to the storage tank with the vacuum pump placed at the top of a 3-m tall ladder to simulate field conditions. The test showed satisfactory results. The gravity and vacuum drains were installed in the inner box (Figure 2), and a 15-cm deep layer of gravel was then added. The gravel would provide storage of excess water at the bottom of the inner box and would allow free movement of water to the gravity drain. A 15-cm deep layer of fine sand was then added on top of the gravel. This layer would act as a filter to prevent soil particles from moving into the gravity drain and into the gravel layer.

\section{Repacking the inner lysimeter box}

The soil to repack the inner lysimeter box was taken from approximately $12 \mathrm{~m}$ south of the lysimeter site. It was attempted to approximate both the soil profile layers and soil density inside the lysimeter box using disturbed soil. The surface dimensions of the inner box $(1.52 \mathrm{~m} \times 1.52 \mathrm{~m})$ were measured and marked in the area where the soil was to be collected. A trench was opened along one of the sides of the marked area with a backhoe. The depths of the soil layers to be collected separately based on the description of the soil profile were marked with flags inside the trench. Each layer was dug out from the marked area with the backhoe and a shovel. The soil from each layer was placed on a dump truck and was placed near the lysimeter site in a separate pile, on a plastic sheet. Once all the layers were collected, the pit was refilled with the soil that had been taken from the lysimeter pit.

Each soil layer was placed inside the inner lysimeter box in the same order and depth it originally had in the field. Care was taken not to compact the soil too much. Instead of compacting the soil mechanically, each time a layer of approximately $0.3 \mathrm{~m}$ was added, the soil was wetted to saturation. The same water tank previously used to pump water out of the north lysim-
Figure 6. Load cells installed at the bottom of the outer lysimeter box. The picture on the right is a close-up picture of one of the three load cells.
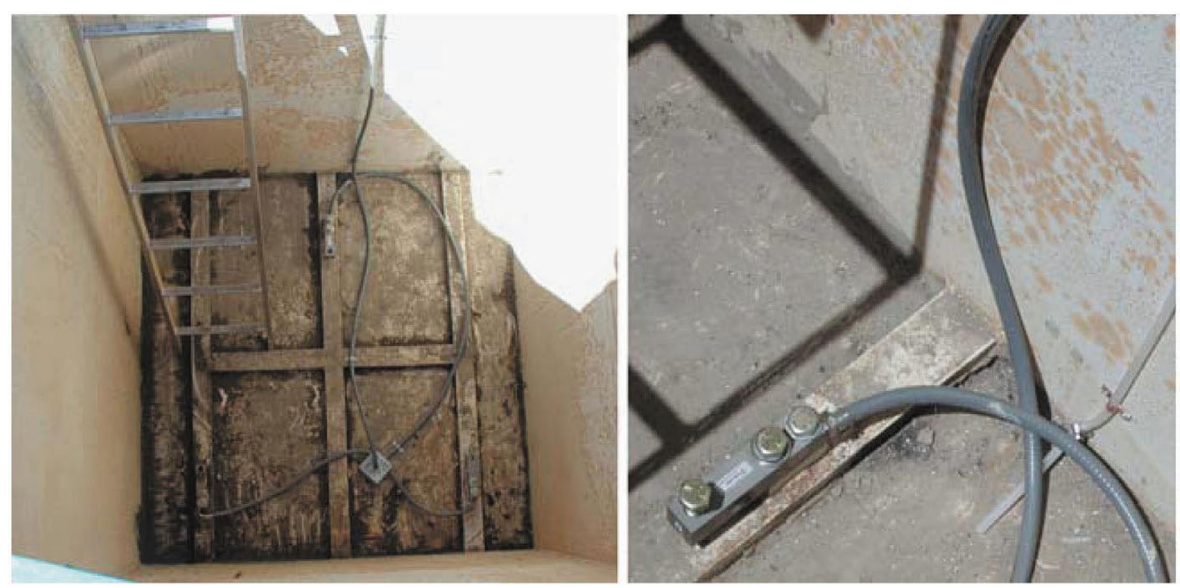
eter pit was used as the water source. At this time, the soil moisture probes and the neutron probe access tube were installed. When all the soil layers were in place, the excess water was allowed to drain to the bottom of the inner box for 2 days and was pumped out with the vacuum pump.

The process used in this study to repack the lysimeter box with soil worked very well. Wetting each soil layer to saturation resulted in a stable soil profile that did not settle further when several rainfall events occurred shortly after installation was completed. Because of these rain events, however, some of the area outside the lysimeters, which were not repacked following the same procedure, settled and had to be refilled. These rainfall events also created drainage that gave us the opportunity to test the vacuum and gravity drainage systems under field conditions. Both systems performed satisfactorily. Wetting the soil inside the lysimeter also helped create good contact between the soil and the suction tubes, soil probes, and neutron probe access tube.

\section{Installing instrument tower}

A model UT20 Universal ${ }^{30}$ 6-m tower and adjustable mast (Campbell Scientific, Inc.) was installed approximately $3 \mathrm{~m}$ north of each lysimeter. The tower was tall enough to install meteorological sensors above the corn canopy. The tower was installed on the north side to avoid shading the lysimeter. It was secured with a buried concrete base $(0.6 \mathrm{~m} \times 0.6 \mathrm{~m} \times 1.2-\mathrm{m}$ deep $)$ to avoid having to install guide wires, which interfere with farming operations. All cables and drainage tubes coming from the lysimeter were placed inside a 50-mm PVC pipe and were buried in a trench (0.3$\mathrm{m}$ wide $\times 0.3-\mathrm{m}$ deep) excavated between the lysimeter and the tower. On the tower, the datalogger was installed inside an enclosure. The vacuum pump was installed inside a plastic enclosure and very close to the ground to minimize lifting head. The vacuum tank and battery were attached to the base of the tower, on top of the concrete base (Figure 3). The solar panel was mounted at a height of $3.7 \mathrm{~m}$, above the maximum corn canopy height.

\section{Calibration procedure}

Each lysimeter was calibrated to convert the load cell outputs to ET units. The calibration consisted of measuring the load cell outputs resulting from loading and unloading the lysimeters with cement bags. Ten $27.3-\mathrm{kg}$ cement bags were used, which corresponded to a water depth of approximately $11.75 \mathrm{~mm}$ per bag. The ten bags $(117.5 \mathrm{~mm})$ represented approximately $80 \%$ of the
$150 \mathrm{~mm}$ maximum soil water depletion that can normally be allowed in this soil without stressing a fullgrown corn crop. One at a time, the bags were loaded in two piles at the center of the lysimeter and then unloaded. The outputs for each load cell and the total output for the three load cells were recorded every time a bag was loaded or unloaded. Once the calibration function was determined, ET during a given period was calculated as:

$$
\mathrm{ET}=R /(b \times A \times K)
$$

where, $\mathrm{ET}=$ evapotranspiration $(\mathrm{mm}), \quad R=$ difference in load cell output $\left(\mathrm{mV} \mathrm{V}^{-1}\right), b=$ slope of the calibration curve $\left(\mathrm{mV} \mathrm{V}^{-1} \mathrm{~kg}^{-1}\right), A=$ effective area of the inner lysimeter box $\left(\mathrm{m}^{2}\right.$ ), and $K=1 \mathrm{~kg} \mathrm{~m}^{-2} \mathrm{~mm}^{-1}$ (since $1 \mathrm{~kg} \mathrm{~m}^{-2}=1 \mathrm{~mm}$ of water). This equation does not take into account mass changes due to factors other than ET, such as rainfall, irrigation, drainage, soil erosion, soil sedimentation, and crop growth.

\section{Results}

\section{Calibration results}

The calibration showed that each lysimeter performed as expected after installation. There was a strong linear relationship between the total load cell output and the changes in total lysimeter mass (Figure 7). The calibration, however, showed some hysteresis when loading and unloading the lysimeters. Since the slope of the calibration line stayed constant, the observed hysteresis was likely due to evaporation occurring while conducting the calibration, which took approximately $1 \mathrm{~h}$ for each lysimeter. Evaporation of soil water could have been minimized by covering the lysimeter with a plastic sheet or a similar material during calibration (Allen and

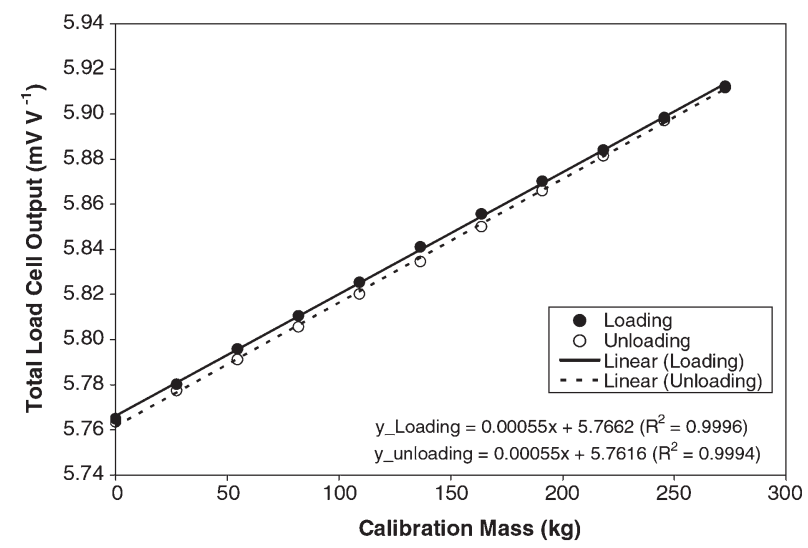

Figure 7. Calibration of south lysimeter at North Platte, NE, USA. The total load cell output is the sum of the outputs of three load cells. 
Fisher 1990). The slopes of the calibration curves were 0.00067 and $0.00055 \mathrm{mV} \mathrm{V}^{-1} \mathrm{~kg}^{-1}$ for the north and south lysimeters, respectively.

Resolution

The resolution of the lysimeter ET measurement is defined as the last significant definable increment of the measurement (Howell et al. 1991). In this study, the lysimeters had a resolution of $0.0001 \mathrm{mV} \mathrm{V}^{-1}$ (Figure 8). This resolution indicates that the differences in load cell output during a given period were stored in multiples of $0.0001 \mathrm{mV} \mathrm{V}^{-1}$ (including negative and positive values), with no values in between. From Eq. 1, it can be calculated that this resolution corresponds to an ET resolution of 0.064 and $0.078 \mathrm{~mm}$ for the north and south lysimeters, respectively.

Howell et al. (1991) and Schneider and Howell (1991) indicated that lysimeter accuracy depends on the lysimeter area, mass, and the type of scale. In the counter-balanced lysimeters at Bushland, TX, USA the most limiting factor was the load cell accuracy (Marek et al. 1988). In this study, however, the lysimeter resolution seemed to be limited by the resolution of the datalogger, instead of that of the load cells. The CR23X datalogger used in this study has an analog voltage resolution of $0.33 \mu \mathrm{V}$ and $15-$ bit resolution in analog to digital conversion. In the highresolution mode, it can only store five digits and a period (5 significant digits). Since the load cell output in these lysimeters has magnitude in the single digits, the output is stored with 4 digits after the period, which means that the resolution of the datalogger is $0.0001 \mathrm{mV} \mathrm{V}^{-1}$. These results suggest that the resolution of the lysimeters could have been improved significantly by choosing a datalogger with a better resolution. For instance, a CR5000 datalogger (Campbell Scientific, Inc.), which can store seven significant figures, instead of five could theoretically increase the resolution 100 times to $0.000001 \mathrm{mV} \mathrm{V}^{-1}$, which would represent an ET resolution of 0.000064 and $0.000078 \mathrm{~mm}$, for the north and south lysimeters, respectively. These values would theoretically have been much better than those shown in Table 1 . However, such good resolutions might not be achievable in practice due to potential limits imposed by the combined error of the load cells and the data acquisition system, and potential influence of environmental factors.

The resolution obtained in this study for the north lysimeter using a CR23X datalogger means that when measuring ET during a given period, an error of $0.064 \mathrm{~mm}$ could occur at both the beginning and the end of the measuring interval, which could be a maximum combined measurement error of $0.128 \mathrm{~mm}$ during the measurement interval. This resolution is adequate for measuring ET for daily and longer periods during the growing season for crops such as corn and soybean. However, it is not accurate enough for hourly of shorter periods or for daily ET measurements during the nongrowing season or winter months, when ET values can be very small. Marek et al. (1988) stated that a resolution of $0.05 \mathrm{~mm} \mathrm{~h}^{-1}$ was necessary to accurately determine hourly ET rates. Figure 9 shows that the percent measurement error decreases as ET increases. With this resolution, values of daily crop ET $\geq 3 \mathrm{~mm}$ would result in measurement error of less than $5 \%$. However, for lower ET values, the percent measurement error increases rapidly. For instance, for an ET value of $0.3 \mathrm{~mm}$, this resolution would result in a measurement error of almost $43 \%$, which would not be an acceptable error. A value of $0.3 \mathrm{~mm}$ would be the average hourly ET for a summer day with a crop ET of $7.2 \mathrm{~mm} \mathrm{day}^{-1}$, which is typical for many agricultural crops in climates similar to that at North Platte.
Figure 8. Hourly difference in load cell output measured with the south lysimeter during 2 days (August 14-15, 2005) at North Platte, NE, USA. During this period, the lysimeter was planted to soybean $($ Plant height $=0.84 \mathrm{~m})$.

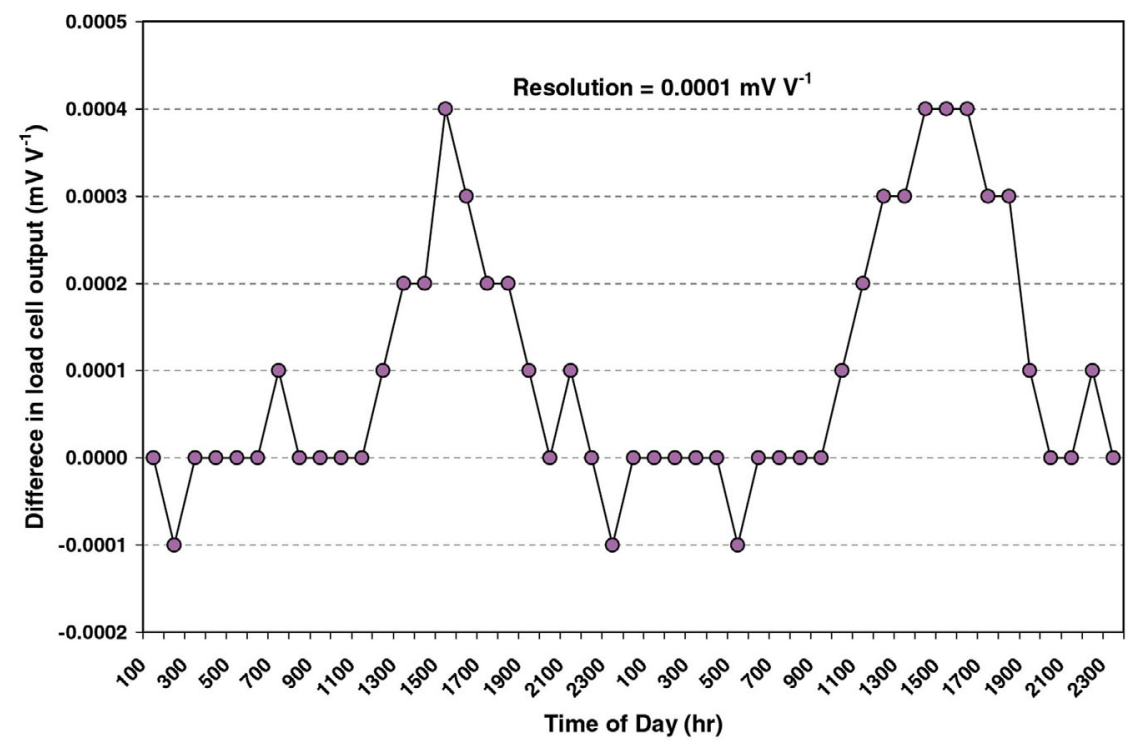




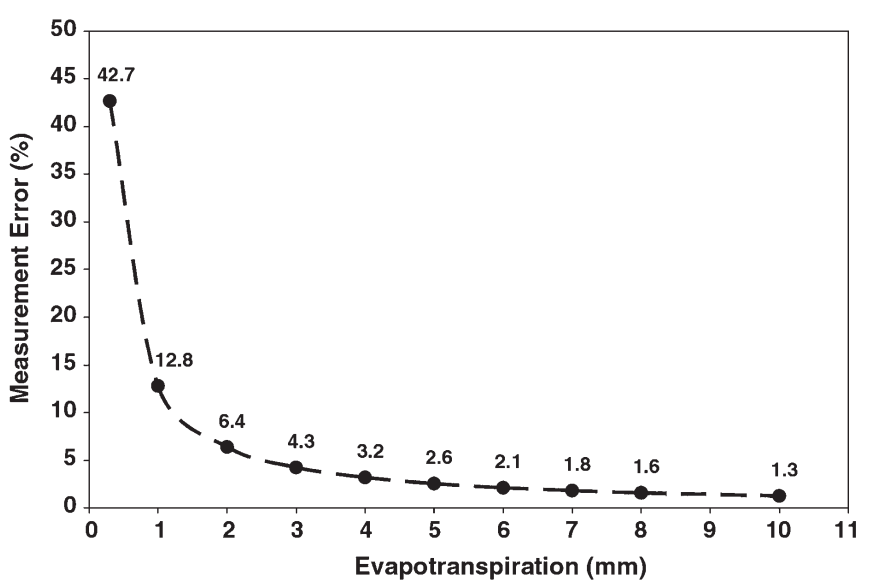

Figure 9. Measurement error calculated as a function of the magnitude of the evapotranspiration (ET) being measured. The measurement error was calculated assuming that the lysimeter had a resolution of $0.064 \mathrm{~mm}$, for one measurement, and twice that $(0.128 \mathrm{~mm})$, combining errors at the beginning and end of the measurement intervals.

The resolution could have been improved by increasing the area of the lysimeters, which would increase the denominator in Eq. 1. Pruitt and Angus (1960) stated that for maximizing the sensitivity, it was necessary to have a relatively large ratio of surface area to volume; therefore, the lysimeter needed to be kept as shallow as possible, without causing unrepresentative root development. For instance, if the lysimeters in this study had twice the area, then the resolution of the north lysimeter would had been $0.032 \mathrm{~mm}$ instead of 0.064 [ET $=0.0001 /$ $\{0.00067(2 \times 2.322)\}]=0.032 \mathrm{~mm}]$. Increasing the area, however, would also increase the total mass, if the depth was kept constant. Figure 10 illustrates how lysimeter resolution can be affected by lysimeter area and datalogger processing and storage resolution.

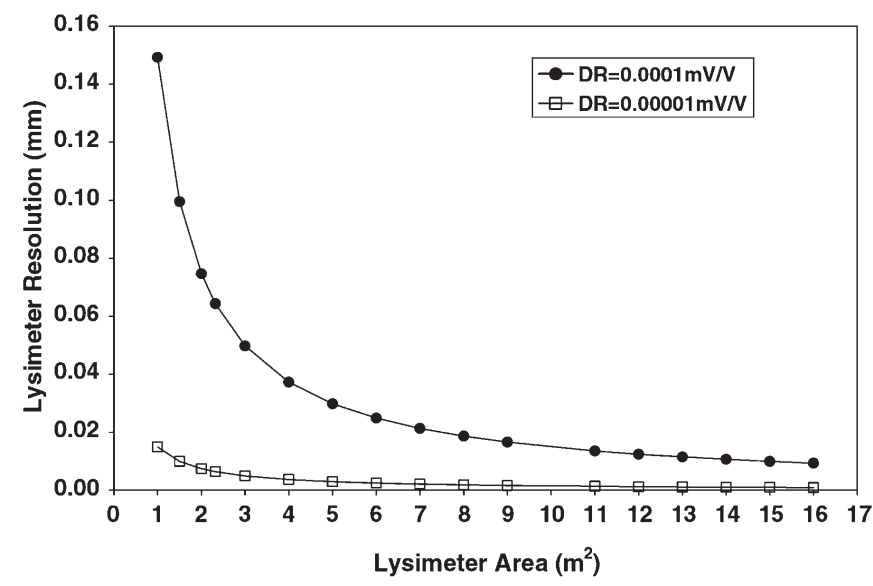

Figure 10. Effect of lysimeter area and datalogger resolution (DR) on potential lysimeter resolution. The lysimeter resolution was calculated with Eq. 1, assuming $b=0.00067 \mathrm{mV} \mathrm{V}^{-1} \mathrm{~kg}^{-1}$.
Cost of construction and installation

The cost of construction and installation of each lysimeter was approximately US $\$ 12,500$ (Table 3 ). This cost only includes material and construction expenses and does not include labor provided by scientists and technicians as part of their regular duties. Furthermore, it only includes the cost of equipment that was rented, but not the cost of equipment that was already available at the research station. Equipment rented included a large crane and a backhoe with a long arm capable of digging to a depth of $2.4 \mathrm{~m}$. Equipment available at the research station included a fork lift, a front loader, a small backhoe, a dump truck, a tractor, a water tank and trailer, etc. Therefore, the total cost can vary significantly depending on the availability and cost of equipment and labor. Also, the cost of operation and maintenance of lysimeters can be significant.

Table 3. Direct cost of building and installing each lysimeter (in 2004 US\$)

\begin{tabular}{lcrr}
\hline Item description & Quantity & Unit cost & Total \\
\hline Fabricating lysimeter boxes & 2 & $\$ 1,330.42$ & $\$ 2,660.84$ \\
Painting lysimeter boxes & 1 & $\$ 100.00$ & $\$ 100.00$ \\
Sand and gravel & 0.5 & $\$ 117.15$ & $\$ 58.58$ \\
Rocks for concrete base & 0.5 & $\$ 331.55$ & $\$ 165.78$ \\
Concrete for lysimeter base & 0.5 & $\$ 200.10$ & $\$ 100.05$ \\
Building storage tank & 0.5 & $\$ 595.59$ & $\$ 297.80$ \\
Building vacuum tank & 1 & $\$ 35.00$ & $\$ 35.00$ \\
Building gravity drain & 0.5 & $\$ 85.68$ & $\$ 42.84$ \\
Tower for datalogger & 1 & $\$ 495.00$ & $\$ 495.00$ \\
Building concrete base for tower & 1 & $\$ 50.00$ & $\$ 50.00$ \\
Datalogger (23X) & 1 & $\$ 2,500.00$ & $\$ 2,500.00$ \\
Datalogger support software & 1 & $\$ 395.00$ & $\$ 395.00$ \\
Datalogger enclosure & 1 & $\$ 335.00$ & $\$ 335.00$ \\
Solar panel & 1 & $\$ 415.00$ & $\$ 415.00$ \\
Car battery & 1 & $\$ 75.00$ & $\$ 75.00$ \\
Backhoe and crane rental & 1 & $\$ 677.16$ & $\$ 677.16$ \\
Load cells and nuts (including spare) & 4 & $\$ 419.75$ & $\$ 1,679.00$ \\
Vacuum pump & 1 & $\$ 191.02$ & $\$ 191.02$ \\
Soil moisture sensors & 6 & $\$ 60.00$ & $\$ 360.00$ \\
Sintered stainless steel porous tubes & 4 & $\$ 205.00$ & $\$ 820.00$ \\
Lumber for concrete base & 0.5 & $\$ 35.20$ & $\$ 17.60$ \\
Labor (student wages) & 0.5 & $\$ 1,148.55$ & $\$ 574.28$ \\
Others (cement, fittings, tubing, etc.) & 1 & $\$ 535.00$ & $\$ 535.00$ \\
Total direct cost & & & $\$ 12,489.93$ \\
\hline & & & \\
\hline
\end{tabular}




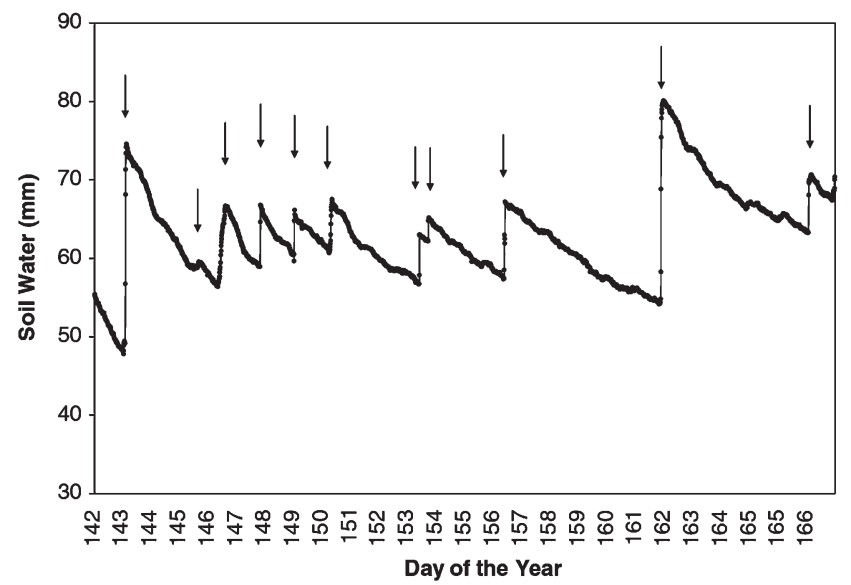

Figure 11. Soil water changes measured with the North lysimeter during May 21 to June 15, 2004 at North Platte, NE, USA. Each point is a 10 -min average. During this period, the surface of the lysimeter was either bare soil or very small soybean. Arrows represent measurable rainfall events.

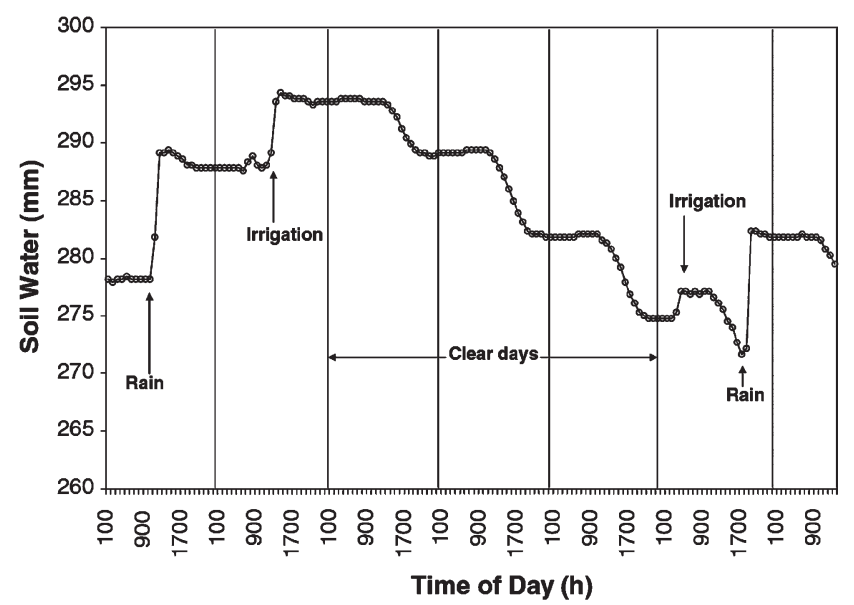

Figure 12. Soil water changes measured with the south lysimeter during a 7-day period (August 12-18, 2005). Each point is an hourly average. During this period, the lysimeter was planted to soybean (plant height $=0.84 \mathrm{~m}$ ). Space between vertical lines represent 1 day.

\section{Performance}

The lysimeters responded to relatively small mass changes. Figure 11 shows that the north lysimeter responded very well to ET and rainfall events early in the growing season. The south lysimeter also responded well to irrigation, rainfall, and crop ET of full-grown soybean (Figure 12). During clear days, the mass of the lysimeter decreased gradually, reflecting changes in crop ET rates, with a steep decrease during the daytime and an almost constant mass during the nighttime, similar to the daily trend reported by Howell et al. (1995). For the future, however, it is recommended that the CR23X datalogger be replaced with a datalogger with better resolution to be able to obtain more accurate hourly and off-season ET measurements. Al- though the lysimeters performed well initially, the main problem has been damage to load cells during the growing season due to lightning strikes during thunderstorm events. This type of problem was not reported by Allen and Fisher (1990), who used a similar design. Since load cells can only be replaced during the off-season, data collection has been severely limited, and future modifications will be needed to address this problem. Options include providing access to the load cells through an access tunnel, installing the load cells close to the surface with the inner box hanging from the load cells (Allen and Fisher 1990), and attaching transient protectors or similar devices to the load cells to protect them against lightning.

\section{Conclusions}

This paper describes the construction, field installation, cost, and performance of two large repacked weighing lysimeters for measuring ET of corn and soybean at North Platte, NE, USA. The total cost of constructing and installing each lysimeter was approximately US $\$ 12,500$, which will vary depending on the availability and cost of equipment and labor. This does not include the cost of operation and maintenance, which can be significant, especially for long-term applications. As expected, the lysimeters responded linearly to changes in total mass and were sensitive to small changes in total mass due to ET, rainfall, and irrigation. Data was stored with a resolution of $0.0001 \mathrm{mV} \mathrm{V}^{-1}$, which was limited by the data storage resolution of the datalogger used in this study. This resolution was equivalent to $0.078 \mathrm{~mm}$ and 0.064 of ET for the north and south lysimeters, respectively. Differences in the ET resolution between the two lysimeters were due to differences in the slopes of their calibration functions. Since the percent measurement error decreases with the magnitude of the ET measured, this resolution is adequate for measuring ET for daily and longer periods, but not for shorter periods. This resolution would result in measurement errors of less than $5 \%$ for measuring ET values of $\geq 3 \mathrm{~mm}$, but the error rapidly increases for lower ET values, becoming unacceptably high for ET values of less than approximately $0.3 \mathrm{~mm}$. The resolution can be improved by selecting a datalogger that can store more significant digits than the one used in this study. Although the lysimeters performed well right after installation, load cell damage due to lightning has been the most important problem. Because of this problem, it is strongly recommended that the load cells be equipped with lightning protection devices and/or installed in such a way that they are accessible and can be replaced during the growing season. 


\section{Acknowledgments}

The authors would like to acknowledge Merle Still, Don Davison, and Jereme Hartman for their valuable contribution to this project. We also would like to acknowledge the help of William C. Markley from the NRCS who described the soil profiles at both lysimeter sites. This paper is a contribution of the University of Nebraska Agricultural Research Division, Lincoln, NE 68583, USA (Journal Series No. 15117). Partial funding for this project was provided by the Anna H. Elliot Foundation.

Names of commercial products are solely provided as information to the reader and do not imply endorsement or recommendation by the authors or their organizations.

\section{References}

Allen RG, Fisher DK (1990) Low-cost electronic weighing lysimeters. Trans ASAE 33:1823-1833

Evett SR, Warrick AW, Matthias AD (1995) Wall material and capping effects on microlysimeter temperatures and evaporation. Soil Sci Soc Am J 59:329-336

Garcia M., Raes D, Allen RG, Herbas C (2004) Dynamics of reference evapotranspiration in the Bolivian highlands (altiplano). Agric For Meteorol 125:67-82

Hanks RJ, Shawcroft RW (1965) An economical lysimeter for evapotranspiration studies. Agron J 57:634-636

Howell TA, McCormick RL, Phene CJ (1985) Design and installation of large weighing lysimeters. Trans ASAE 28:106-112, 117

Howell TA, Schneider AD, Jensen ME (1991) History of lysimeter design and use for evapotranspiration measurements. In: Proceedings of the conference on lysimeters for evapotranspiration and environmental measurements, IR Div/ASCE/Honolulu, 23-25 July, pp 1-9

Howell TA, Schneider AD, Dusek DA, Marek TH, Steiner JL (1995) Calibration and scale performance of the Bushland weighing lysimeters. Trans ASAE 38:1019-1024

Hunsaker DJ, Pinter PJ Jr, Cai H (2002) Alfalfa basal crop coefficients for FAO-56 procedures in the desert regions of the southwestern US. Trans ASAE 45:1799-1815

Kirkham RR, Gee GW, Jones TL (1984) Weighing lysimeters for longterm water balance investigations at remote sites. Soil Sci Soc Am J 48:1203-1205

Klocke NL, Heermann DF, Duke HR (1985) Measurement of evaporation and transpiration with lysimeters. Trans ASAE 28:183-189, 192

Klocke NL, Todd RW, Hergert GW, Watts DG, Parkhurst AM (1993) Design, installation, and performance of percolation lysimeters for water quality sampling. Trans ASAE 36:429-435

Klocke NL, Watts DG, Schneekloth JP, Davison DR, Todd RW, Parkhurst AM (1999) Nitrate leaching in irrigated corn and soybean in a semi-arid climate. Trans ASAE 42:1621-1630

Laubach J, Raschendorfer M, Kreilein H, Gravenhorst G (1994) Determination of heat and water vapor fluxes above a spruce forest by eddy correlation. Agric For Meteorol 71:373-401

Liu J, Kotoda K (1998) Estimation of regional evapotranspiration from arid and semi-arid surfaces. J Am Water Resour Assoc 34:27-41

Malone RW, Bonta JV, Stewardson DJ, Nelsen T (2000) Error analysis and quality improvement of the Coshcton weighing lysimeters. Trans ASAE 43:271-280

Marek TH, Schneider AD, Howell TA, Ebeling LL (1988) Design and construction of large weighing monolithic lysimeters. Trans ASAE 31:477-484
Marek TH, Piccinni G, Schneider AD, Howell TA, Jett M, Dusek DA (2006) Weighing lysimeters for the determination of crop water requirements and crop coefficients. Appl Eng Agric 22:851-856

McFarland MJ, Worthington JW, Newman JS (1983) Design, installation and operation of a twin weighing lysimeter for fruit trees. Trans ASAE 26:1717-1721

Meshkat M, Warner RC, Walton LR (1999) Lysimeter design, construction, and instrumentation for assessing evaporation from a large undisturbed soil monolith. Appl Eng Agric 14:303-308

Payero JO (2005) Using weighing lysimeters to improve accuracy of crop water use data, project report, University of Nebraska-Lincoln, North Platte, Nebraska, pp 36

Payero JO, Neale CMU, Wright JL, Allen RG (2003) Guidelines for validating Bowen ratio data. Trans ASAE 46:1051-1060

Payero JO, Klocke NL, Schneekloth JP, Davison DR (2006) Comparison of irrigation strategies for surface-irrigated corn in West Central Nebraska. Irrig Sci 24:257-265

Phene CJ, McCormick RL, Davis KR, Pierro JD, Meek DW (1989) A lysimeter feedback irrigation controller system for evapotranspiration measurements and real time irrigation scheduling. Trans ASAE 32:477-484

Pruitt WO, Angus DE (1960) Large weighing lysimeter for measuring evapotranspiration. Trans ASAE 3:13-15, 18

Schneider AD, Howell TA (1991) Large, monolithic, weighing lysimeters. In: Proceedings of the conference on lysimeters for evapotranspiration and environmental measurements, IR Div/ASCE/ Honolulu, 23-25 July, pp 37-45

Schneider AD, Marek TH, Ebeling LL, Howell TA, Steiner JL (1988) Hydraulic pulldown procedure for collecting large soil monoliths. Trans ASAE 31:1092-1097

Schneider AD, Howell TA, Steiner JL (1993) An evapotranspiration research facility using monolithic lysimeters from three soils. Appl Eng Agric 9:227-235

Schneider AD, Ayars JE, Phene CJ (1996) Combining monolithic and repacked soil tanks for lysimeters from high water table sites. Appl Eng Agric 12:649-654

Schneider AD, Howell TA, Moustafa ATA, Evett SR, Abou-Zeid W (1998) A simplified weighing lysimeter for monolithic or reconstructed soils. Appl Eng Agric 14:267-273

Seyfried MS, Hanson CL, Murdock MD, Van Vactor S (2001) Longterm lysimeter database, Reynolds Creek experimental watershed, Idaho, United States. Water Resour Res 37:2853-2856

Todd RW, Evett SR, Howell TA (2000a) The Bowen ratio energy balance method for estimating latent heat flux of irrigated alfalfa evaluated in a semi-arid, advective environment. Agric For Meteorol 103:335-348

Todd RW, Evett SR, Howell TA, Klocke NL (2000b) Soil temperature and water evaporation of small steel and plastic lysimeters replaced daily. Soil Sci 165:890-895

Tyagi NK, Sharma DK, Luthra SK (2003) Determination of evapotranspiration for maize and berseem clover. Irrig Sci 21:173-181

van Bavel CHM, Myers LE (1962) An automatic weighing lysimeter. Agric Eng 43:580-583, 586-588

Verhoef A, Allen SJ, Lloyd CR (1999) Seasonal variation of surface energy balance over two sahelian surfaces. Int J Climatol 19:1267-1277

Yang SL, Aydin M, Yano T, Li X (2003) Evapotranspiration of orange trees in greenhouse lysimeters. Irrig Sci 21:145-149

Yoder RE, Odhiambo LO, Wright WC (2005) Evaluation of methods for estimating daily reference crop evapotranspiration at a site in the humid southeast United States. Appl Eng Agric 21:197-202

Young MH, Wierenga PJ, Mancino CF (1997) Monitoring near-surface soil water storage in turfgrass using time domain reflectometry and weighing lysimetry. Soil Sci Soc Am J 61:1138-1146 